\title{
Experimental and Theoretical Calculation of Efficiency for Flat Plate Solar Collectors in Erbil City
}

\author{
Iyd Eqqab Maree', Ayad Ghany Ismaeel ${ }^{2}$, \\ ${ }^{1}$ Department of Mechanical and Energy, Erbil Polytechnic University, Iraq, Erbil. \\ ${ }^{2}$ Department of Computer Science, Al - Kitab University, Iraq, Erbil,
}

\section{Article Info}

Received Mar 10, 2019

\section{Keyword:}

Solar energy

Flat plate collector

Efficiency

Solar collector

\begin{abstract}
Solar plate collectors are utilized to heat up water or a mixture of water and glycol by capturing solar radiation and transfer this heat to the collector fluid. In this study, the efficiency of solar plate collector during 19th, 20th and 21st of February, was investigated experimentally. The time of day, plate collector mean temperature, solar intensity and external air temperature can effect on the efficiency of solar collector. And the effect of incidence angle on solar irradiation has been studied; as a result, the solar irradiance will be decreased as the angle of incidence increased. A method presented can be used to calculate hour angle, diffuse solar radiation and total solar radiation at various temperatures in this paper its MATLAB programs.
\end{abstract}

\section{Corresponding Author:}

First Author,

Department of Mechanical and Energy Engineering,

Erbil Polytechnic University,

Iraq - Erbil - Kirkuk Road.

Email: aiyed67@gmail.com

\section{Introduction}

Nowadays, the solar flat plate collector is widely used to transfer as well as absorb solar energy radiation for working in low-temperature (up to $60^{\circ} \mathrm{C}$ ) or medium temperature (up to $100^{\circ} \mathrm{C}$ ). The solar thermal energy has increased and become a significant source of renewable energy, because of increase in the effect of the environmental as well as rising cost of fuels type (i.e., oil or gas, such as the heating of the global, greenhouse effects, the pollution of the air, reduction of the ozone layer. The solar thermal systems, photovoltaic (PV), as well as designing passive solar are a principal input for solar thermal energy application of solar radiation data for optimization, designing and evaluation of the efficiency of solar technologies for any position, a reliable as well as readily available data is needed. Due to unable to afford the techniques involved and measuring equipment, the measurements of solar radiation is difficult for various developing countries. To evaluate the amount of solar energy radiation on the horizontal plane surface, many models have been invented by utilizing the climatic parameters, minimum and maximum the temperature of the ambient, humidity, sunshine duration and the speed of the wind [1-6]. For appropriate designing of solar energy systems, as well as a great evaluation of thermal energy surrounding within buildings, the acknowledge of the local solar radiation is important for that purpose [7-11]. Solar thermal energy collector is a type of heat exchanger that converts solar radiation energy which is coming from the sun into internal energy [12]. Solar collector absorbs the solar 
radiation energy and transforms it into heat then this heat is transferred to a fluid that passes through the collector, where the absolute performances of various material such as collector absorbing, glazing materials, as well as utilized fluids are used to estimate these conversions.

Mongre and Gupta [13] experimentally studied the solar collector efficiency by combining the system of the solar collector water heater with a circulating pump and utilizing of aluminum tube. As a result, by increasing the glazing area the efficiency of the system was increased by 55.24\%. The solar plate collector performance has been calculated experimentally under specified outdoor and indoor test procedures $[14,15]$. Weitbrecht et al. [16] investigated solar flat plate collector experimentally. The distribution of fluid flow pass through the collector has been observed. Hammad [17] reported that the solar plate collector performance which is cooled by a set of heat pipes, manufactured and designed to operate at low-temperature conditions. As a results, the efficiency of the system was fulfilled about $60 \%$, where the value of this efficiency was equal to that of the water cooled collector. Miguel et al. correlation [18, 19] have been implemented to determine the hourly values of diffuse as well beam components of solar irradiance from global total solar irradiance. Rasmussen and Svendsen [20] performed a simulation program SOLEFF, for determining the efficiency of solar flat plate collectors. Merriam et al.[21] investigated that for high-temperature outputs, the solar flat plate collectors are not frequently used. The solar flat plate collector suffers from the losses of the heat because of convection, conduction. The losses of heat increase with the working fluid temperature [22]. The present aim of this paper is to experimentally calculate the efficiency of solar plate collector on 19th, 20th, and 21st February for various water temperatures.

\section{Experimental method procedures}

The analysis of the thermal solar collector flat plate which is made of copper plate was performed experimentally. To absorb solar energy radiation, the absorber of the black solar flat plate collector which is covered with a double glass of $6 \mathrm{~mm}$. The material of mineral wool of thickness $4.6 \mathrm{~cm}$ was utilized to insulate the bottom of the solar collector to minimize the loss of the heat through the absorber plate which is occurred by conduction. The earth rotates about its axis in every 24 hours, this revolution gives $15^{\circ}$ for every 1 hour. A water reservoir was made of aluminum with a capacity of 196 liters, thickness $5 \mathrm{~mm}$, and thermal conductivity of $204.2 \mathrm{~W} /(\mathrm{m} . \mathrm{K})$ was used to supply water to the collector. The experiments were conducted with coordinates $\left(36.2063^{\circ} \mathrm{N}, 44.0089^{\circ} \mathrm{E}\right)$ on 19th, 20th and $21 \mathrm{st}$ February 2015 . The temperatures were taken through a thermocouple every 30 min during daylight from 8:30 am to 2:30 pm and with changing the sun position, the position of the solar plate collector was changed as well. Regarding the diffuse radiation as well as direct radiation, the location of the solar collector was oriented to receive both of them. The solar plate collectors are influenced extremely by the angle of inclination [23, 24]. The maximum value of solar plate collector was achieved with $45^{\circ}$ of inclination angle from a horizontal surface. The water is circulated due to density difference; the discharges of water and the temperature of the ambient were $1.89 \mathrm{liter} / \mathrm{min}$ and $31^{\circ} \mathrm{C}$, respectively. By utilizing the thermocouple, the input and outlet water temperature were measured. Figure 1 shows the solar flat plate collector components.

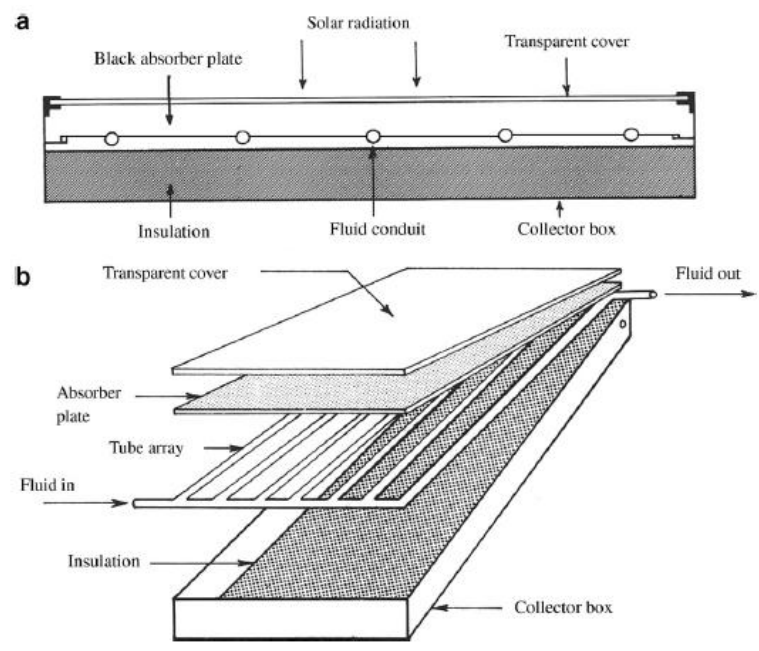


Fig. 1 Solar collector components. [25]

\section{Mathematical Modeling}

The $\delta$ can be calculated from equation of [26].

$$
\delta=23.45 \sin \left(360 \frac{284+n}{365}\right)
$$

Where $n$ is the day of the year and obtained from [30]. Thus, $1<n<365$.

$$
B=(n-1) \frac{360}{365}
$$

The beam incidence angle radiation on a surface $\theta$ can be calculated as;

$$
\begin{gathered}
\cos \theta=\sin \delta \sin \emptyset \cos \beta-\sin \delta \cos \emptyset \sin \beta \cos \gamma+\cos \delta \cos \emptyset \cos \beta \cos \omega \\
+\cos \delta \sin \emptyset \sin \beta \cos \omega
\end{gathered}
$$

The sun zenith angle, $\theta_{z}$ can be calculated as;

$\cos \theta_{z}=\cos \delta \cos \varnothing \cos \omega+\sin \emptyset \sin \delta$

The solar time and standard time can be calculated according to:

$$
\text { Solar time }- \text { standard time }=4\left(L_{s t}-L_{1 o c}\right)+E
$$

The equation of time and can be calculated from

$$
\begin{aligned}
& E=229.2(0.000075+0.001868 \cos B-0.032077 \sin B-0.014615 \cos 2 B \\
& \quad-0.04089 \sin 2 B)
\end{aligned}
$$

The solar plate collector thermal energy lost can be find from the following equation.

$$
\mathrm{Q}_{\mathrm{u}}=F_{R} * \mathrm{~A}_{\mathrm{c}}\left[G_{s c} * \tau * \alpha-\mathrm{U}_{\mathrm{L}}\left(\mathrm{T}_{\mathrm{pm}}-\mathrm{T}_{\mathrm{a}}\right)\right]
$$

Where $A_{c}$ is the Collector area, $G_{s c}$ Solar constant, $\tau$ the transmittance, $\alpha$ the Absorptance.

Equation (8) which is known as the "Hottel-Whillier-Bliss equation" is commonly utilized relationship for measuring collector energy. The value of $\mathrm{F}_{\mathrm{R}}$ can be calculated as:

Where $\mathrm{F}^{\prime}$ can be taken as $0.841[27]$

$$
F_{R}=\frac{\dot{m} C_{p}}{A_{c} U_{L}}\left[1-\exp \left(-\frac{A_{c} U_{L} F^{\prime}}{\dot{m} C_{p}}\right)\right]
$$

The collector solar radiation received is determined by:

Where the value of $G_{s c}$ is $1367\left(\mathrm{~W} / \mathrm{m}^{2}\right)$.

$$
\left(\mathrm{Q}_{\mathrm{i}}\right)=G_{s c} * \mathrm{~A}_{\mathrm{c}}
$$

A collection efficiency cab be found from equation:

Substitute eq. (10) in eq. (11) we get:

$$
\eta=\frac{\mathrm{Q}_{\mathrm{u}}}{\mathrm{Q}_{\mathrm{i}}}
$$

$$
\begin{gathered}
\eta=\frac{\mathrm{Q}_{\mathrm{u}}}{G_{s c} * \mathrm{~A}_{\mathrm{c}}} \\
\eta=\frac{F_{R} * \mathrm{~A}_{\mathrm{c}}\left[G_{s c} * \tau * \alpha-\mathrm{U}_{\mathrm{L}}\left(\mathrm{T}_{\mathrm{pm}}-\mathrm{T}_{\mathrm{a}}\right)\right]}{G_{s c} * \mathrm{~A}_{\mathrm{c}}} \\
\eta=F_{R} * \tau * \alpha-F_{R} * \mathrm{U}_{\mathrm{L}}\left(\frac{\mathrm{T}_{\mathrm{pm}}-\mathrm{T}_{\mathrm{a}}}{G_{s c} *}\right)
\end{gathered}
$$

The direct irradiance of solar rays can be expressed as [281]:

$$
\mathrm{I}_{\mathrm{DN}}=\mathrm{A} \exp \left(-\frac{\mathrm{B}}{\operatorname{sina}}\right)
$$

Where (a) is the solar altitude, A is the apparent solar irradiance at zero air mass, and B is the extinction coefficient. For 21 February $A=1215\left(\mathrm{~W} / \mathrm{m}^{2}\right), B=0.144\left(\mathrm{~W} / \mathrm{m}^{2}\right)$ and $C=0.06\left(\mathrm{~W} / \mathrm{m}^{2}\right)[29]$ :

The solar elevation angle can be determined from

Diffuse radiation from the sky

$$
\sin a=\cos \emptyset \cos \delta \cos \omega+\sin \emptyset \sin \delta
$$

$\mathrm{F}_{\mathrm{ws}}$ view factor is given by

$$
\mathrm{I}_{\mathrm{d}}=\mathrm{C} * \mathrm{I}_{\mathrm{DN}} * \mathrm{~F}_{\mathrm{ws}}
$$




$$
\mathrm{F}_{\mathrm{ws}}=\frac{1+\cos \beta}{2}
$$

The value of $\beta$ for horizontal is $0^{\circ}$ and for vertical surface is $90^{\circ}$. Also, the reflected shortwave (solar) radiation can be expressed as:

$$
I_{r}=\left(I_{D N}+I_{d}\right) * \rho g * F_{w g}
$$

Where $\rho g=0.6$ is the reflectivity of the ground, and $F_{w g}$ is the view factor between the surface and earth, is calculated by:

$$
F_{w g}=\frac{1-\cos \beta}{2}
$$

The total solar irradiance $I_{T}\left(\mathrm{~W} / \mathrm{m}^{2}\right)$ of a surface of any orientation can be calculated according to this formula.

$$
I_{T}=I_{D N} * \cos \theta+I_{d}+I_{r}
$$

\section{Discussion and Results}

The experimental test was performed to evaluate the efficiency of the solar plate collector in environmental conditions. The data of temperatures were taken during 13 hours from 8:30 am to 2:30 pm and translate it into MATLAB program and the following results were obtained.

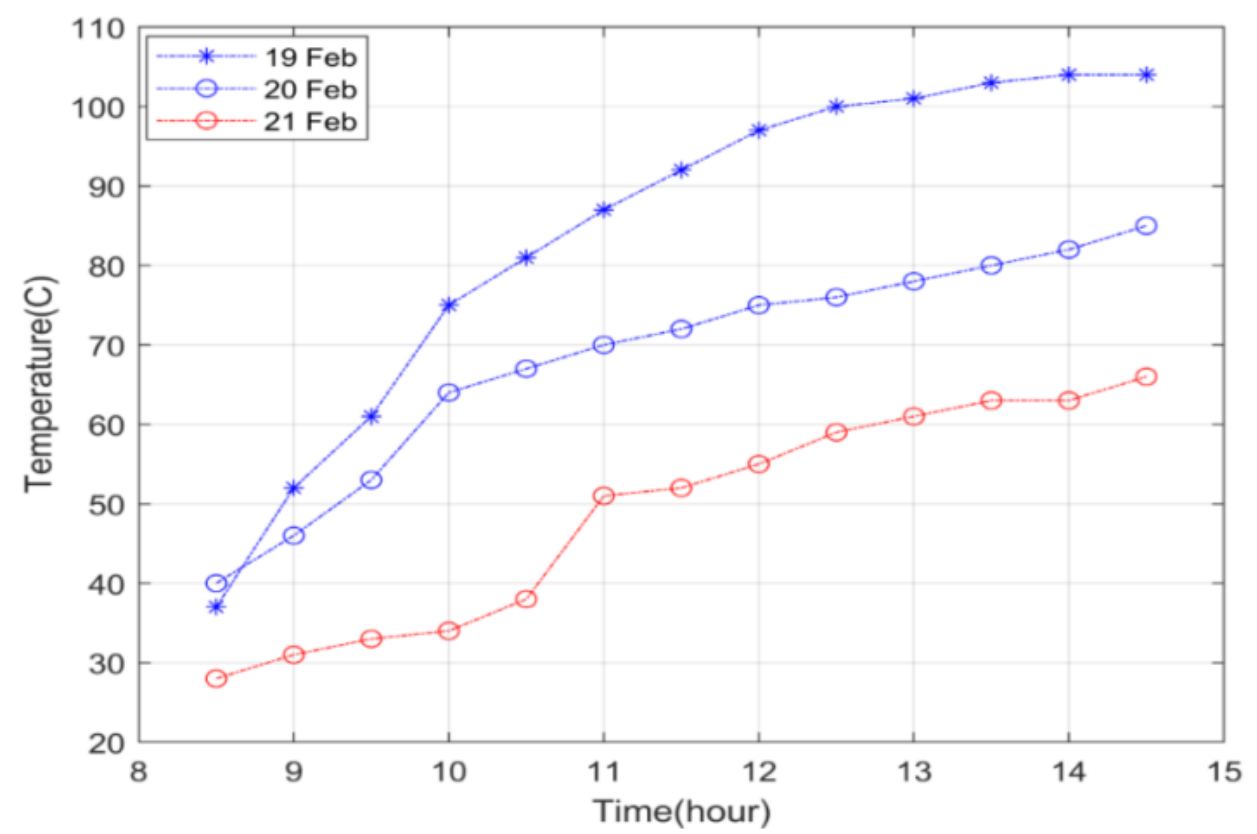

Fig. 2 The temperature of the water variation with solar time on 19th, 20th and 21st February

Figure 2 presents the temperature of the water variation with time in a sunny day of 19th, 20th, and 21th February 2018. The temperature of the water increases as the time increases from 8:30 to 14:30. It is seen that the maximum water temperature at $2: 30 \mathrm{pm}$ occurred. The maximum possible water temperature of solar collector on 19th, 20th and 21 st was achieved as $104^{\circ} \mathrm{C}, 85^{\circ} \mathrm{C}$ and $66^{\circ} \mathrm{C}$, respectively. Figure 3 depicts the variation of solar collector efficiency with hourly time. It is clear that as time increased the collector efficiency is decreasing gradually. It can be easily observed that, the solar plate collector on 21st February gives maximum efficiency is of $74.8 \%$ at the beginning of the day. The diffuse irradiance $I_{d}$ was calculated based on equation (17) for various values of the angle of incidence $\theta$ for $\left(36.2063^{\circ} \mathrm{N}\right.$ latitude, $44.0089^{\circ} \mathrm{E}$ longitude). Figure 4 illustrates the relationship between diffuse irradiance $I_{d}$ and incidence angle $\theta$ at tilt angle $40^{\circ}$. The results show that as the angle of incidence increases the diffuse irradiance decreases. It is also noticed that on 19th, 20th, and 21st February there is a few differences between the value of diffuse irradiance $I_{d}$. As shown in Figure 5 the total solar irradiance $\left(\mathrm{I}_{\mathrm{T}}\right)$ which is calculated from Eq. (21) is plotted against the hourly time. The maximum value of solar energy irradiation $\left(\mathrm{I}_{\mathrm{T}}\right)$ occurs at solar noon and reached about $170 \mathrm{~W} / \mathrm{m}^{2}$ on 
19th February. After $12 \mathrm{pm}$ it started to decrease until reached $115 \mathrm{~W} / \mathrm{m}^{2}$. The curve of the solar irradiance $\left(\mathrm{I}_{\mathrm{T}}\right)$ is smooth that means there is no effect of atmospheric conditions such as cloud cover.

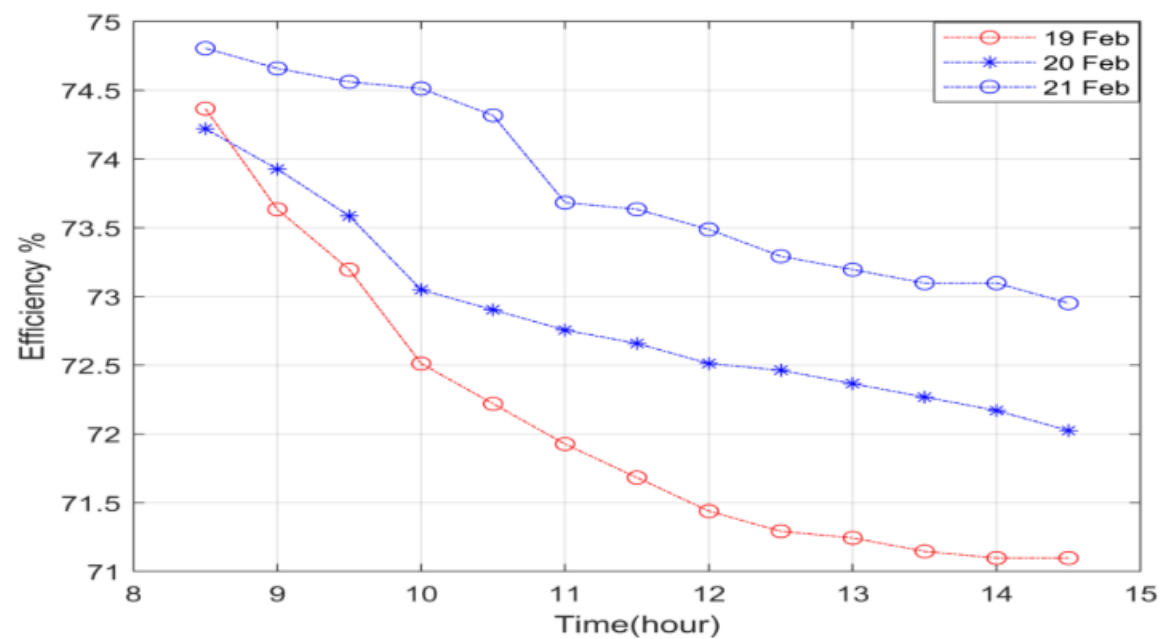

Fig. 3 The collector efficiency variation with a solar time on 19th, 20th and 21st February

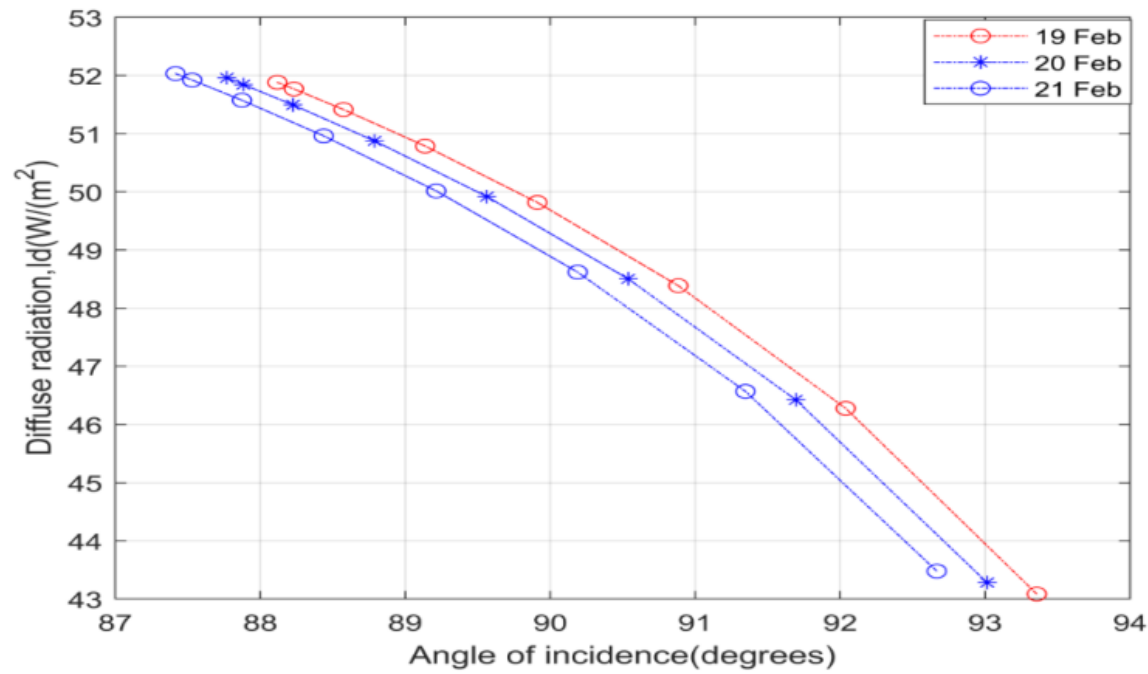

Fig. 4 The diffuse radiation variation with solar time

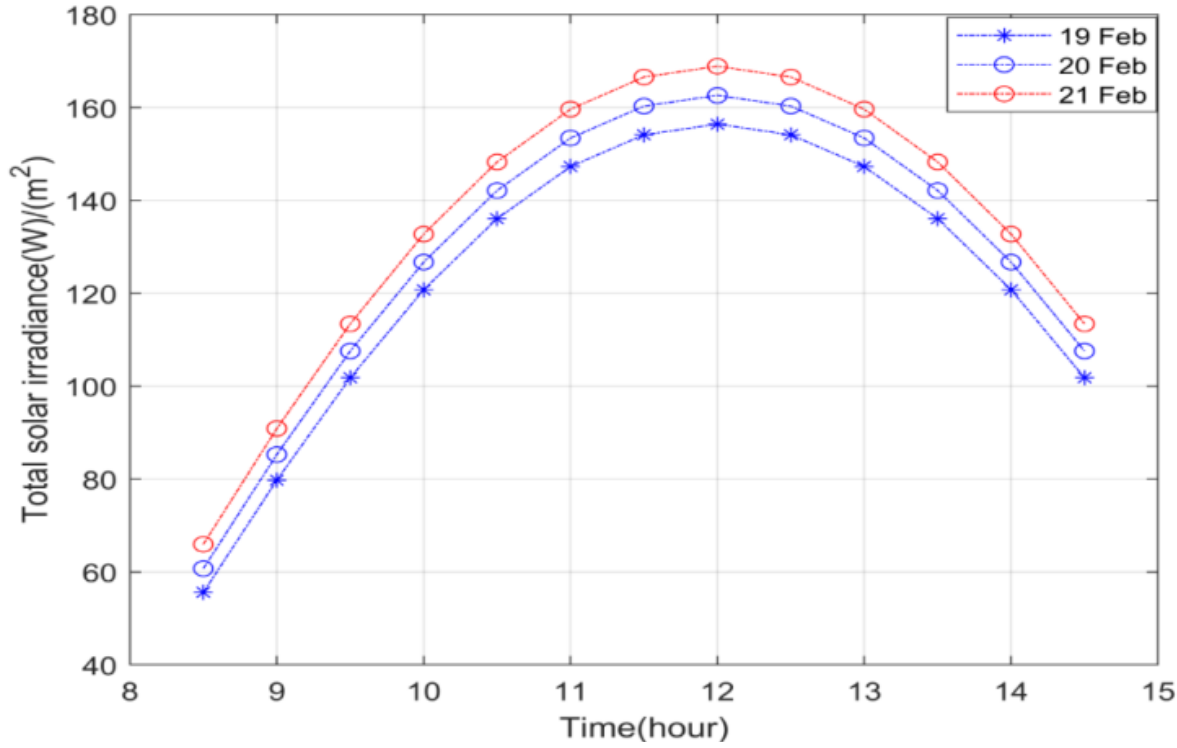

Fig. 5 Daily changes of total solar energy irradiation 


\section{Conclusion}

The main objective of this paper was a determination efficiency of solar plate collector which is the ratio of the thermal energy useful over incident solar energy. The efficiencies of solar plate collectors are strongly depending on solar radiation as well the temperature of the external air. The efficiency of solar collector decreased as time increased conversely, the temperature of water outlet increased with time. For an ambient temperature of $31^{\circ} \mathrm{C}$, the maximum value of solar collector efficiency on 19th, 20th, and $21 \mathrm{st}$ was achieved as $74.4 \%, 74.3 \%$, and $74.8 \%$. On the other hand, the measured data were utilized to determine the relationship between incidence angle with a diffuse radiation, and total solar irradiance with hourly time, the results show that the diffuse radiation inversely changed with incidence angle and the highest possible value of solar irradiance can be achieved at solar noon.

\section{Nomenclature}

\author{
$A_{c}$ Collector area $\left(\mathrm{m}^{2}\right)$ \\ $\mathrm{T}_{\mathrm{a}} \quad$ Ambient temperature $\left({ }^{\circ} \mathrm{C}\right)$ \\ $\mathrm{C}_{\mathrm{P}} \quad$ Specific heat $(\mathrm{kj} / \mathrm{kg} . \mathrm{K})$ \\ $\mathrm{U}_{\mathrm{L}} \quad$ Heat transfer coefficient $\left(W / \mathrm{m}^{2} K\right)$ \\ E Energy, equation of time \\ $\alpha$ Absorptance \\ $\mathrm{F}_{\mathrm{R}}$ Collector heat removal factor \\ $\beta$ Tilt angle, degrees \\ $\mathrm{F}^{\prime} \quad$ Collector efficiency factor \\ $\gamma$ Surface azimuth angle, degrees \\ $\mathrm{G}_{\mathrm{sc}}$ Solar constant, $\left(\mathrm{W} / \mathrm{m}^{2}\right)$ \\ $\delta \quad$ Declination, degrees \\ $\mathrm{I}_{\mathrm{DN}}$ Direct solar irradiance $\left(\mathrm{W} / \mathrm{m}^{2}\right)$ \\ $\eta \quad$ Efficiency $\%$ \\ $L_{s t}$ standard meridian \\ $L_{10 c}$ longitude of the location
}

\author{
$\mathrm{I}_{\mathrm{d}} \quad$ Diffuse radiation $\left(\mathrm{W} / \mathrm{m}^{2}\right)$ \\ $\theta$ Angle of incidence, degrees \\ $\mathrm{I}_{\mathrm{r}}$ Reflected radiation $\left(\mathrm{W} / \mathrm{m}^{2}\right)$ \\ $\rho g$ Reflectivity of the ground \\ $\mathrm{I}_{\mathrm{T}} \quad$ Total solar irradiance $\left(\mathrm{W} / \mathrm{m}^{2}\right)$ \\ $\tau$ Transmittance \\ $\dot{m}$ Mass flow rate $(\mathrm{kg} / \mathrm{s})$ \\ $\emptyset \quad$ Latitude, degrees \\ $\mathrm{Q}_{\mathrm{u}}$ Thermal energy lost(W) \\ $\omega$ Hour angle, degrees \\ $\mathrm{S}$ radiation absorbed flux $\left(\mathrm{W} / \mathrm{m}^{2}\right)$ \\ $\alpha$ Absorptance \\ $\mathrm{T}_{\mathrm{pm}}$ absorber plate temperature $\left({ }^{\circ} \mathrm{C}\right)$ \\ a Solar altitude
}

\section{References}

[1] M. Chegaar and A. Chibani, "Global solar radiation estimation in Algeria," Energy conversion and management, vol. 42, pp. 967-973, 2001.

[2] I. Supit and R. Van Kappel, "A simple method to estimate global radiation," Solar Energy, vol. 63, pp. 147-160, 1998.

[3] N. Halouani, C. Nguyen, and D. Vo-Ngoc, "Calculation of monthly average global solar radiation on horizontal surfaces using daily hours of bright sunshine," Solar energy, vol. 50, pp. 247-258, 1993.

[4] K. Gopinathan, "A general formula for computing the coefficients of the correlation connecting global solar radiation to sunshine duration," Solar energy, vol. 41, pp. 499-502, 1988.

[5] A. A. Sabziparvar and H. Shetaee, "Estimation of global solar radiation in arid and semi-arid climates of East and West Iran," Energy, vol. 32, pp. 649-655, 2007.

[6] C. Jacovides, F. Tymvios, V. Assimakopoulos, and N. Kaltsounides, "Comparative study of various correlations in estimating hourly diffuse fraction of global solar radiation," Renewable Energy, vol. 31, pp. 2492-2504, 2006.

[7] Z. Lu, R. Piedrahita, and C. dos Santos Neto, "Generation Of Daily And Hourly Solar Radiation Values For Modelingwater Quality In Aquaculture Ponds," Transactions of the ASAE, vol. 41, p. $1853,1998$.

[8] M. Machler and M. Iqbal, "A modification of the ASHRAE clear sky irradiation model," ASHRAE transactions, vol. 91, pp. 106-115, 1985. 
[9] T. Cartwright, "Here comes the Sun: solar energy from a flat-plate collector," Modelling the World in a Spreadsheet-Environmental Simulation on a Microcomputer, pp. 121-144, 1993.

[10] J. H. S. Trujillo, "Solar performance and shadow behaviour in buildings. Case study with computer modelling of a building in Loranca, Spain," Building and Environment, vol. 33, pp. 117-130, 1998.

[11] D. H. Li and J. C. Lam, "Solar heat gain factors and the implications to building designs in subtropical regions," Energy and Buildings, vol. 32, pp. 47-55, 2000.

[12] S. A. Kalogirou, "Solar thermal collectors and applications," Progress in energy and combustion science, vol. 30, pp. 231-295, 2004.

[13] P. K. Mongre and B. Gupta, "Experiment study of solar water heater with circulating pump and using of Aluminum tube," International Journal of Engineering Trendsand Technology, vol. 3, 2013.

[14] B. Solarenergie, "Gebrauchstauglichkeit yon Solarkollektoren, Teil A," Wirkungsgradtest von Solarkollektoren Essen, 1980.

[15] J. E. Hill and E. R. Streed, "A method of testing for rating solar collectors based on thermal performance," Solar Energy, vol. 18, pp. 421-429, 1976.

[16] V. Weitbrecht, D. Lehmann, and A. Richter, "Flow distribution in solar collectors with laminar flow conditions," Solar Energy, vol. 73, pp. 433-441, 2002.

[17] M. Hammad, "Experimental study of the performance of a solar collector cooled by heat pipes," Energy conversion and management, vol. 36, pp. 197-203, 1995.

[18] A. M. Noorian, I. Moradi, and G. A. Kamali, "Evaluation of 12 models to estimate hourly diffuse irradiation on inclined surfaces," Renewable energy, vol. 33, pp. 1406-1412, 2008.

[19] A. De Miguel, J. Bilbao, R. Aguiar, H. Kambezidis, and E. Negro, "Diffuse solar irradiation model evaluation in the north Mediterranean belt area," Solar Energy, vol. 70, pp. 143-153, 2001.

[20] P. Rasmussen and S. Svendsen, "SolEff Program til beregning af solfangeres effektivitet," Thermal Insulation Laboratory, Technical University of Denmark, 1996.

[21] M. Merriam, "Materials technology for flat plate steam generator," in Proc. Solar Heating and Cooling for Buildings Workshops, 1973.

[22] G. Vishal, V. Chinmay, and R. Kishor, "Solar water heating systems: A review," Int. J. Sci. Eng. Res.(IJSER), vol. 3, pp. 13-17, 2015.

[23] J. Sarkar, "Performance of a flat-plate solar thermal collector using supercritical carbon dioxide as heat transfer fluid," International Journal of Sustainable Energy, vol. 32, pp. 531-543, 2013.

[24] H. Tabaei and M. Ameri, "Improving the effectiveness of a photovoltaic water pumping system by using booster reflector and cooling array surface by a film of water," Iranian Journal of Science and Technology. Transactions of Mechanical Engineering, vol. 39, p. 51, 2015.

[25] A. Sözen, T. Menlik, and S. Ünvar, "Determination of efficiency of flat-plate solar collectors using neural network approach," Expert Systems with Applications, vol. 35, pp. 1533-1539, 2008.

[26] P. Cooper, "The absorption of radiation in solar stills," Solar energy, vol. 12, pp. 333-346, 1969.

[27] J. A. Duffie and W. A. Beckman, Solar engineering of thermal processes: John Wiley \& Sons, 2013.

[28] D. A. Stewart, H. P. Dudel, and L. J. Levitt, "Solar Radiation in Saudi Arabia," ARMY MISSILE COMMAND REDSTONE ARSENAL AL WEAPONS SCIENCE DIRECTORATE1993.

[29] L. Wong and W. Chow, "Solar radiation model," Applied Energy, vol. 69, pp. 191-224, 2001. 


\section{BIBLIOGRAPHY OF AUTHORS (11 PT) (Optional)}

Assist Prof. Dr. IYD EQQAB MAREE received MSC in Mechanical Engineering from the University of Technology, Baghdad-IRAQ at

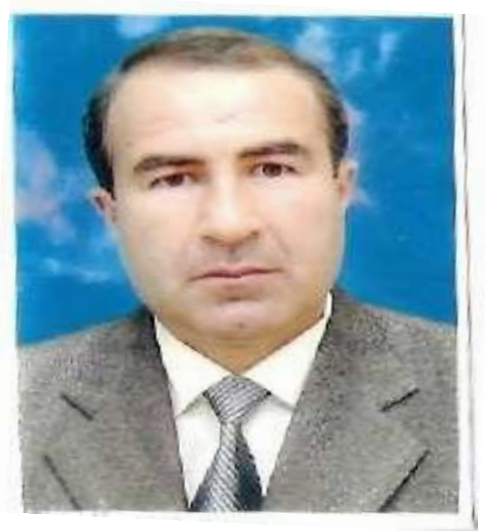
June. 2005, and Ph.D. TU-Freiberg, Germany in 2016. Currently a Head of Mechanical and Energy Engineering Department Erbil Polytechnic University-Erbil-IRAQ. I teaching and supervising undergraduate and postgraduate students in many qualifications like: wind energy, solar energy, Fluid Mechaincs, Thermal power, and Published more than 20 paper in the word.

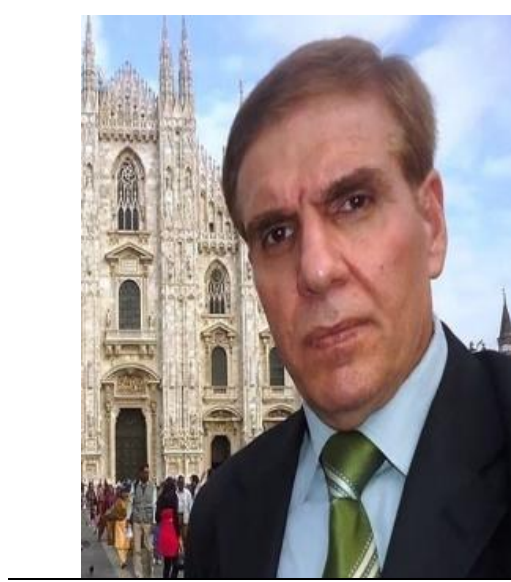

Prof. Dr. Ayad Ghany Ismaeel received MSC in computer science from the National Center of Computers NCC- Institute of Postgraduate Studies, Baghdad-IRAQ at May. 1987, and Ph.D. Computer science in qualification of computer and IP network from University of Technology, Baghdad- IRAQ in 2006, visit URL: goo.gl/gn8pK4 . Currently a president of Al-Kitab University-Kirkuk-IRAQ, he was a dean of Alkitab University College-Kirkuk-IRAQ till Sep. 2018, visit URL: https://www.uoalkitab.edu.iq/eng, and he is professor at 7 Aug. and he is teaching and supervising undergraduate and postgraduate students in many qualifications like: Computer Science, Information Systems Engineering, Bioinformatics, Biotechnology, Cloud Computing, Healthcare/Embedded Systems, Mobile Network. 